Korytko T., Kruk 0.

\title{
IMPROVEMENT OF TAX POLICY OF TERRITORIAL COMMUNITIES IN THE CONTEXT OF BUDGET DECENTRALIZATION
}

Об’єктом дослідження є процес вдосконалення податкової політики на рівні територіальних громад з урахуванням особливостей проведення бюджетної децентралізації. Одним з найбільи проблемних місиь є перерозподіл податкових надходжень між рівнями бюджетної системи. Існуючий розподіл не сприяє стимулюванню органів місцевого самоврядування до мобілізації $і$ пошуку джерел активізацї власних економічних ресурсів щодо реалізацї соціальних програм та підвищення інвестиційної активності територіальної громади. Вдосконалення податкової політики пов'язано з необхідністю підвищення рівня бюджетної самостійності органів місцевого самоврядування.

Проведено аналіз сучасного стану доходів державного та місиевого бюджетів у частині формування податку на прибуток підприємств, а також фінансових результатів і рівня рентабельності операційної діяльності за видами промислової діяльності підприємств. На основі методу екстраполяиї проведено прогнозування суми податку на прибуток підприємств. Визначено структуру перерозподілу податку на прибуток підприємств між рівнями бюджетної системи. Впровадження структури перерозподілу податку на прибуток підприємств між рівнями бюджетної системи ускладнено відсутністю системності процесу децентралізащї.

В ході дослідження використовувалися системний підхід, методи аналізу і синтезу та метод екстраполящї для прогнозування суми податку на прибуток підприємств. Визначено основні напрямки вдосконалення податкової політики на рівні територіальних громад в контексті бюджетної децентралізації.

Завдяки цьому забезпечується можливість підвищення інвестиційної активності підприємств, що знаходяться в межах певної територіальної громади. У порівнянні з існуючою структурою розподілу податку на прибуток підприємств між рівнями бюджетної системи запропонований підхід дозволяє забезпечити стимулювання місцевих органів до пошуку джерел активізації власних економічних ресурсів щодо реалізаиї соціальних програм. А також підвищення інвестиційної активності територіальної громади.

Ключові слова: податкова політика, податок на прибуток підприємств, територіальна громада, бюджетна децентралізація.

\section{Introduction}

Ukraine in modern conditions is characterized by a difficult internal economic situation, due to the instability of macroeconomic indicators and the decentralization of government. Fiscal decentralization provides local governments with greater autonomy, expanding their powers to make management decisions at the level of the territorial community. The decentralized system is aimed at providing an appropriate level of kindness and public services to the population of the territorial community, taking into account their preferences and incentives, aimed at improving the efficiency and quality of the provision of such services.

Reliable and timely information on the status of tax revenue generation is necessary for the effective redistribution of taxes between budgets of different levels. The existing model of budgetary relations in Ukraine is characterized by excessive centralization of tax revenues, asymmetry between obligations and revenues of local governments.

When implementing the implementation of directions for improving tax policy at the level of territorial communities in the context of fiscal decentralization, there are certain difficulties and problems associated with changes in fiscal legislation. It is possible to ensure effective redistribution of corporate income tax between budgets of various levels due to changes in the distribution of mobilized amounts. Thus, the study of tax decentralization processes is an urgent problem and requires further solutions.

\section{The object of research and its technological audit}

The object of research is the process of improving tax policy at the level of territorial communities, taking into account the specifics of fiscal decentralization.

Improving tax policy in the context of fiscal decentralization should not be viewed as a separate problem that needs to be resolved at the level of territorial communities, but as part of the country's overall tax policy.

So, one of the biggest problem areas is the study of aspects of tax decentralization in the implementation of proposals for the distribution of corporate income tax between budgets of different levels taking into account the specifics of the formation of their revenue side. Despite the large number of scientific works on solving this problem, there remain controversial questions on the development of directions for improving tax policy at the level of territorial communities. 


\section{The aim and objectives of research}

The aim of research is clarification of the role of tax revenues in the formation of budgets of territorial communities in the context of fiscal decentralization. To achieve the aim of research the following objectives are defined:

1. To conduct a modern analysis of state and local budget revenues in terms of the corporate income tax, as well as financial results and the level of profitability of the operating activities of enterprises.

2. To determine the main directions of improving tax policy at the level of territorial communities in the context of fiscal decentralization.

\section{Research of existing solutions of the problem}

Works of many leading scientists are devoted to the study of the theoretical and methodological aspects of improving tax policy and its tools in the context of fiscal decentralization.

[1-3] is devoted to the study of formation of the structure of the budget system and fiscal decentralization in Ukraine. But not enough attention is paid to building a state with clear signs of fiscal decentralization. That is why it is necessary to explore the scientific achievements of those foreign scientists who have studied the processes of decentralization in foreign countries in order to highlight certain positive steps in this direction and apply best practices in the domestic practice of financial relations.

The founder of the theory of fiscal decentralization [4] notes that fiscal decentralization increases the level of competition between local authorities, with the result that the volume of the public sector is significantly limited.

At the same time, in work [5], fiscal decentralization is defined as the right of local governments to independently decide on financial issues and issues on territorial management. Decentralization is a way of measuring the magnitude of the transition of a national economy from command to market economy. As the author of [6] notes, fiscal decentralization should be simple, take into account all levels of government and meet the goals of the decentralization reform.

In theory, decentralization means the transfer of responsibility for the increase in expenditure and revenue parts of the budget to the local level [7]. The choice of a particular model of intergovernmental regulation is a rather complicated issue for each state. The study of the classification and choice of types of interbudget regulation models has been widely reflected in the works of many scientists and practitioners [8].

In his studies, the author of [9] focuses on the need for structural reforms in the implementation of fiscal relations in the financial crisis between the levels of government. At the same time, as the author of [10] notes an important indicator of the level of fiscal decentralization is the share of own revenues in the income structure of the territorial community.

Among the main tax sources for filling the budgets of territorial communities, it is advisable to highlight [11]:

- taxation of private consumption, carried out in the relevant territory;

- taxation of income of citizens or profits of enterprises located and receive their income in this territory;
- taxation of factors of production located in a certain territory.

Thus, the results of literary analysis suggest that fiscal decentralization provides significant powers to local authorities in the formation of local budget revenues and is an important tool for the development of regions, therefore, its research is promising.

\section{Methods of research}

General scientific and special research methods were applied during the execution of the work:

- analysis and synthesis - for preliminary analysis with the formation of the problem, the definition of goals; to study the characteristics and analysis of the current state of incomes of state and local budgets in terms of the corporate income tax. As well as financial results and the profitability level of the operating activities of enterprises;

- analogies and comparative comparisons - to determine directions for improving tax policy at the level of territorial communities;

- extrapolation method - to predict the amount of tax on corporate profits.

\section{Research results}

Revenues of the budgets of territorial communities serve as a source of funding for the socio-economic development of territories and ensuring their investment activity. However, the processes of fiscal decentralization are not systematic and do not contribute to encouraging local authorities to find sources of enhancing their own economic resources to implement social programs and increase the investment activity of the territorial community.

One of the stimulating tools for increasing the investment activity of the territorial community is tax policy. Therefore, it is necessary to shift the emphasis in the economic regulation of investment activity to the level of territorial communities. This is due to the acute need of territories for investment resources, especially cities that are located in the territory of Donetsk and Luhansk regions (Ukraine). One of the ways to improve the investment climate of the territorial community is increasing the efficiency of the enterprises operating in this territory. Therefore, profit is the main source of reproduction of the enterprise, therefore, to increase the economy, it is necessary to maximize its volume at the disposal of the enterprise.

State participation in the regulation of investment activity through the conduct of tax policy is carried out using tools such as tax rates and tax incentives. So, by determining the optimal tax rate and using the system of tax incentives that affect investment processes, one can regulate the demand for investments.

It should be noted that the income tax plays an important role in the regulation of the economy. The tax rate is in 2015-2017 - $18 \%$. Also, for enterprises, which from 01.12.2016 have capital investments, are made possible to reduce tax liabilities.

The dynamics of corporate income tax to the state budget is shown in Fig. 1. In 2017 compared with 2013, there is an increase in the amount of corporate income tax by 4.5 billion USD and the reduction of part of this tax in the structure of state budget revenues to $9.8 \%$. 


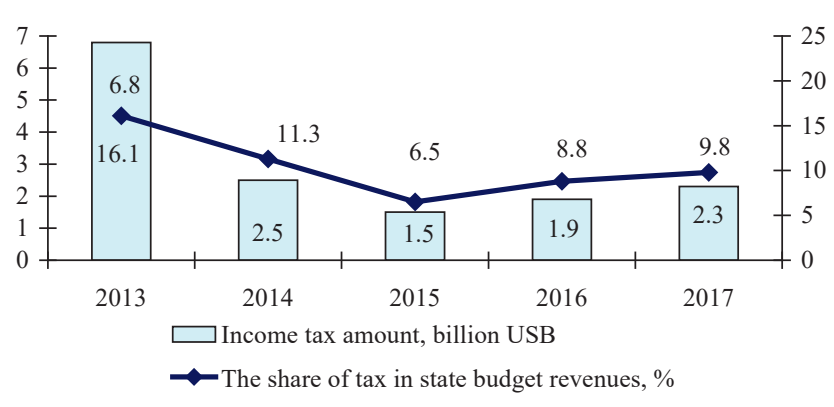

Fig. 1. Dynamics of corporate income tax in state budget during 2013-2015 [12]

During 2013-2017 indicators of the financial result of enterprises before tax are deteriorating due to the political and economic crises in Ukraine (Fig. 2).

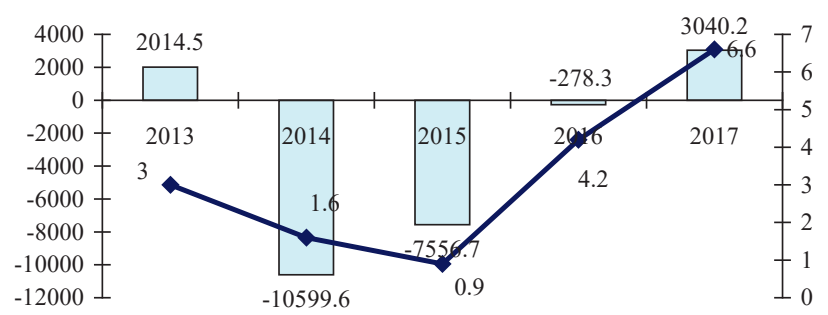

$\square$ Financial results of enterprises by type of industrial activity, million USD

$\neg$ Profitability of operating activities by type of industrial activity, $\%$

Fig. 2. Dynamics of financial results of enterprises and the level of profitability of operating activities by type of industrial activity during 2013-2017 [12]

In 2017, the financial result before taxation by type of industrial activity of enterprises amounted to 3040.2 million USD, which is 1025.7 million USD more than in 2013. It can be noted that the level of profitability over the 2013-2017 increased to $6.6 \%$

The growth of the financial performance of enterprises indicates an increase in the amount of tax on their profits in the budgets of local levels (Fig. 3).

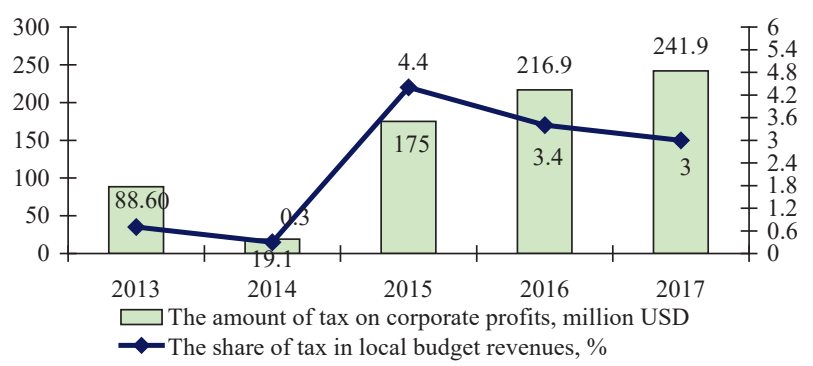

Fig. 3. Dynamics of the volume of income from the tax on profits of enterprises in the budgets of local levels during 2013-2017 [12]

According to Fig. 3, the volume of income from the tax on the profits of enterprises to local budgets, starting from 2014, is characterized by a tendency to increase, which indicates the strengthening of the fiscal role of this tax payment. Another reason for the increase in corporate income tax is to reduce its rate from $19 \%$ in 2013 to $18 \%$ in 2017 This, on the one hand, reduces the tax burden on the business, and on the other, increases the fiscal role of this tax caused by changes in the mechanism of its redistribution between the links of the budget system.
Let's conduct a forecast of the tax on the profits of enterprises using the extrapolation method (Fig. 4)

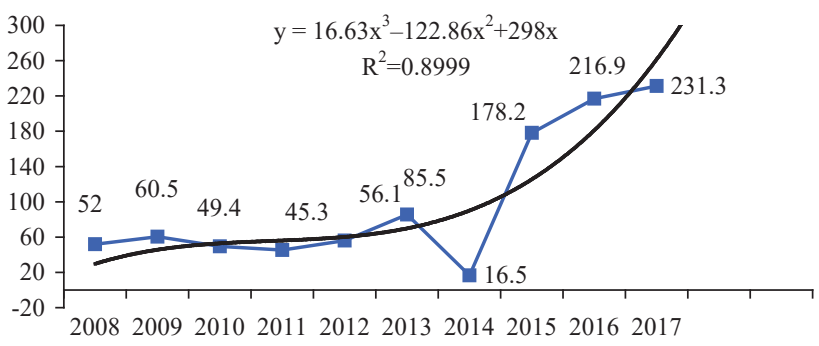

Fig. 4. Dynamics of the volume of income from the tax on profits of enterprises in the budgets of local levels during 2008-2019, million USD

Let's calculate the amount of tax on corporate profits in 2018-2019:

- 2018:

$Y=16.63 \cdot 11^{3}-122.86 \cdot 11^{2}+298 \cdot 11=375.25$ million USD;

$-2019$

$Y=16.63 \cdot 12^{3}-122.86 \cdot 12^{2}+298 \cdot 12=520.3$ million USD.

From the calculation, it can be noted that the amount of revenues of local budgets will increase, which will affect the increase in investment activity of the territorial community in the context of fiscal decentralization.

In order to increase the budgetary independence of the territorial community, it is necessary to carry out further tax policy reform. The further development of the processes related to the granting of greater powers to local authorities requires that they be granted certain rights to collect taxes and fees in their own territory in amounts sufficient to meet the needs of local development.

If transfer the authority to administer a corporate income tax to local governments, then this tax will not forge the redistributive function, through which the principle of the budget system is implemented - the principle of social justice. It will also disrupt the financial balance between different territorial communities. So, the transfer of corporate income tax in the amount of $100 \%$ to local budgets will not solve the problem of increasing the budgetary independence and investment activity of the territorial community. Therefore, it is necessary to find such a ratio in the redistribution of this tax between the various links of the budget system, which would ensure an increase in the socio-economic development of the territories, and it is also necessary not to forget about the unevenness of various territorial communities.

It is important to create a favorable investment climate in the economy at the territorial level is conducting an effective tax policy aimed at increasing investment activity. It is the use of tax regulation methods that will solve this problem. Using the tools of tax policy, it is possible to create a favorable mode for self-financing of entrepreneurial activity at the expense of profits and accumulated depreciation deductions for sectors of the economy, taking into account the peculiarities of territorial development. Therefore, when developing tax policy measures aimed at regulating investment activity, it is important to envisage a system of guarantees for using the received financial 
resources (or their parts) for the goals set by the state, primarily for investment and innovation development.

The provision of targeted tax incentives guarantees the state almost $100 \%$ of the use of financial resources for the purposes it pursues when applying this or that privilege. At the same time, tax benefits are an integral element of the regulatory mechanism of tax policy and an effective instrument for financing investments. They affect the amount of investment resources, so they must be used purposefully to stimulate investment activity.

To increase the level of investment activity of territorial communities through tax policy mechanisms, the following areas should be considered:

- direction of the regulatory mechanism of tax policy to stimulate the development of production not only in special economic zones, but also outside these zones; - instead of reducing the rates of basic taxes using a broader system of tax benefits;

- wide provision of exemptions and exemptions on taxes and fees in part, credited to local budgets;

- concentration of tax revenues from small businesses in local budgets in order to support small businesses and stimulate investment in the real economy;

- introduction of a tax benefit, which provides for full or partial exemption from the corporate income tax of a part of the received profit, aimed at investment activity, or return of the investment tax benefit;

- increase in the size of the investment tax credit provided to the enterprise during research and development, or technical re-equipment of its own production from 30 to $100 \%$ of the value of the purchased equipment; - strengthening tax control over enterprises engaged in industries with significant shadow turnover;

- consideration of the possibility of granting tax holidays for a period of 3-5 years for enterprises introducing high technologies, machines, equipment, and innovations, which are the statutory period, which are exempted from tax payment;

- reforming the investment tax credit should be carried out by:

1) expansion of the scope of the investment tax credit; 2) expansion of the list of taxes for which this loan can be issued;

3) revision in the direction of increasing the amount of the corresponding tax, which can be used to obtain an investment tax credit, as well as the timing of its provision; 4) a significant expansion of tax rights and powers of local authorities in terms of the formation in the relevant territory of a favorable investment climate, the introduction of additional tax incentives in order to attract investment in the economy of the territory; 5) use of tax incentives and easing the tax burden for enterprises investing in the implementation of priority territorial development programs (agriculture, investment activities, innovative projects, small business), in particular the creation of special economic zones of local importance.

The main condition for the implementation of the tax policy measures discussed above should be the use by the taxpayer of a part of the financial resources released for investment purposes.

Directions of territorial tax policy in terms of regulating investment activity should be active in nature, that is, purposefully contribute to increasing the investment and production potential of the territorial community.

\section{SWOT analysis of research results}

Strengths. The strengths of research and the proposed directions for improving tax policy at the level of territorial communities are that these measures help to increase their budgetary independence. Compared to other approaches to improve tax decentralization, this can be done through the redistribution of corporate income tax between budgets of different levels. So, the proposed directions allow to make sound effective management decisions and stimulate the initiatives of local authorities on investment revitalization.

Weaknesses. The analysis of budget revenues shows that one of the key sources of their formation is the corporate income tax. So, the transfer of a part of the corporate income tax to the budgets of territorial communities will increase their budgetary autonomy. The weak side of the proposed distribution of corporate income tax between budgets of various levels is the impossibility of its independent use by local governments.

Opportunities. It should be noted that in the future, tax decentralization may be supplemented with proposals on tax incentives for enterprises. Since tax breaks are an integral element of the regulatory mechanism of tax policy and an effective tool for financing investments. They affect the amount of investment resources, so they must be used purposefully to stimulate investment activity.

Threats. The threats of tax decentralization include the fact that even the proposed directions for improving tax policy at the level of territorial communities are not a dogma, which makes it possible to avoid reducing the budgetary independence of local governments. In particular, due to the inability of local governments to influence changes in fiscal legislation. The situation is complicated by the fact that local authorities can't influence the redistribution process of national taxes at the legislative level.

\section{Conclusions}

1. The analysis of state and local budget revenues in terms of corporate income tax, as well as financial results and the level of profitability of the operating activities of enterprises are carried out. The structure of the redistribution of taxes on profits of enterprises between the levels of the budget system is defined. The introduction of the structure of the redistribution of corporate income tax between the levels of the budget system is hampered by the lack of a systematic decentralization process.

2. The main directions for improving tax policy at the level of territorial communities in the context of fiscal decentralization are identified. They provide the possibility of increasing the investment activity of enterprises located within a certain territorial community. This allows to provide incentives for local authorities to find sources for enhancing their own economic resources for the implementation of social programs and to increase the investment activity of the territorial community.

\section{References}

1. Bulyeyev I. P., Korytko T. Yu., Kruk O. M. Management of budget budgets. Kramatorsk: DDMA, 2013. 310 p.

2. Lunina I. P. Formulation of budget budgets on the basis of the principle of equi-valence: a step towards effective budgetary system // Finance of Ukraine. 2010. Vol. 9. P. 3-12.

3. Polyak A. V. The Experience of Local Taxation in Germany and Its Use in the Reform of the Tax System of Ukraine // 
Bulletin of the Zaporizhzhya National University. 2014. Vol. 4, Issue 1. P. 188-194.

4. Tiebout C. Economic Theory of Fiscak Decentralzation // Public Finances: Sources, and Utilization. Princeton, 1961. P. 79-96.

5. Bell M., Adams C. Fiscal Decentralization Indicators: Local Democratic Governance // Proceedings of 92' annual conference. Atlanta: National Tax Association, 1999. P. 236-241.

6. Bahl R. Implementation Rules for Fiscal Decentralization. Atlanta, 1999. URL: http://siteresources.worldbank.org/INTDSRE/Resources/3p.pdf

7. Reingewertz Y. Fiscal Decentralization - a Survey $f$ the Empirical Literature // MPRA Paper No. 9889. 2014. 46 p. doi: http:// doi.org/10.2139/ssrn.2523335

8. Rodriguez-Pose A., Ezcurra R. Is fiscal decentralization harmful for economic growth? Evidence from the OECD countries // Journal of Economic Geography. 2010. Vol. 11, Issue 4 P. 619-643. doi: http://doi.org/10.1093/jeg/lbq025

9. Vammalle C., Hulbert C. Sub-national Finances and Fiscal Consolidation: Walking on Th in Ice // OECD Regional Development Working Papers. 2013. doi: http://doi.org/10.1787/5k49m8cqkcf3-en
10. Sow M., Razafimahefa I. Fiscal Decentralization and the Efficiency of Public Service Delivery // IMF Working Papers New York: International Monetary Fund, 2015. Vol. 15, Issue 59. doi: http://doi.org/10.5089/9781484351116.001

11. Pedreja-Chaparro F., Salinas-Jimenez J., Suarez-Pandisllo J. Financing local governments: the Spanish experience // International Studies Program, Andrew Young School of Policy Studies, Georgia State University. 2006. Vol. 06-11. P. 11-12.

12. State Statistics Service of Ukraine. URL: http://www.ukrstat gov.ua/

Korytko Tetyana, PhD, Associate Professor, Department of Problems of Enterprise Economics, Institute of Industrial Economics of National Academy of Sciences of Ukraine, Kyiv, Ukraine, e-mail: Korytko@nas.gov.ua, ORCID: http://orcid.org/0000-0002-4251-1971

Kruk Olena, PhD, Associate Professor, Department of Finance, Banking and Entrepreneurship, Donbass State Engineering Academy, Kramatorsk, Ukraine, ORCID: http://orcid.org/0000-00025659-6603
Khalatur 5., Zubkova Yu.

\section{IMPROVEMENT OF METHODOLOGICAL PRINCIPLES OF FINANCIAL RESOURCES MANAGEMENT OF ENTERPRISES IN ECONOMY OF UKRAINE}

Об’єктом дослідження є фінансово-економічні відносини, що виникають в процесі управління фінансовими ресурсами підприємств в умовах нащіональної економіки України. Одним з найбільш проблемних місць є необхідність описати зв'язок між конкурентною стратегією підприємств на основі управління їх фінансовими ресурсами.

В процесі дослідження фінансових ресурсів як об’єкта фінансового менеджменту були використані методи індукиї і дедукиї, аналізу і синтезу. На основі методів інтерпретацї, системного і ретроспективного аналізу, спостереження, порівняння та графічного зображення результатів дослідження здійснювались оцінка динаміки та структури фінансових ресурсів підприємств України. При обгрунтуванні рекомендацій з удосконалення системи управління фінансовими ресурсами суб'єктів підприємництва національної економіки України були застосовані методи системності, комплексності, логічного моделювання.

Результати дослідження показали, що існують певні зв'язки при формуванні конкурентних стратегій підприємств на основі ефективності використання фінансових ресурсів. Підприємства національної економіки Украйни повинні формувати належні конкурентні стратегї, щоб покращити свої фінансові показники в мінливих економічних умовах. Слід знати та застосовувати відповідні стратегї, які стосуються ефективності використання фінансових ресурсів підприємств: корпоративний розвиток, функціональний рівень, ресурси та детермінанти вимірювання фінансової ефективності в різних економічних періодах. Ефективність управління фінансовими ресурсами підприємств начіональної економіки Украйни сприяє здатності до можливостей і стійкості до загроз, які існують в їх економічному середовищі, та забезпечить безперервний успіх підприємства.

Завдяки успішній реалізацї методологічних засад управління фінансовими ресурсами забезпечується можливість:

- відображати синтез інструментів зростання вартості підприємства (фінансового менеджменту);

- забезпечення потокового управління фінансовими ресурсами;

- формування чінності для всіх учасників ринку і суспільства (маркетингу);

- виявлення факторів та резервів створення цінності та вартості (фінансового аналізу);

- формування інформацї для емпіричного тестування моделей оцінювання (бухгалтерського обліку).

Ключові слова: конкурентні стратегї підприємств, ефективність управління фінансовими ресурсами, національна економіка України.

\section{Introduction}

Financial resources are assets of enterprises that influence the choice and possibilities of conducting financial and economic activities of business entities. Paradoxically, but in the flawless market, financial decisions of enterprises do not affect the corporate value, and financial resources are thus largely irrelevant. The possibility of increasing 